\title{
ANALISIS TINDAK TUTUR DIREKTIF DALAM NOVEL BELENGGU KARYA ARMIJN PANE (SUATU TINJAUAN PRAGMATIK)
}

\begin{abstract}
Hajarti
Abstak :

Penelitian ini bertujuan untuk memperoleh gambaran dan penjelasan tentang Analisis Tindak Tutur Direktif dalam Novel Belenggu Karya Armijn Pane (suatu Tinjauan Pragmatik). Jenis penelitian ini adalah penelitian pustaka yang bersifat deskriptif kualitatif yang menggunakan ancangan teori pragmatik. Sumber data dalam penelitian ini adalah novel yang berjudul Belenggu karya Armijn Pane. Hasil analisis data menunjukkan bahwa tindak tutur direktif yang ditemukan dalam novel Belenggu karya Armijn Pane, terdiri dari tiga bentuk, yaitu : (1) kalimat imperatif; (2) kalimat introgatif; (3) kalimat deklaratif. Wujud tindak tutur direktif itu digunakan dalam tindak tutur memesan, memerintah, memohon, menyarankan, meminta, mengajak, menentang, menasihati dan melarang. Tindak tutur direktif dalam novel Belenggu karya Armijn Pane diwujudkan dengan modus tuturan yang bervariasi dan dengan fungsi yang berbeda-beda. Hal itu digunakan untuk menjalin hubungan sosial sesuai dengan norma sosial budaya yang mereka miliki.
\end{abstract}

\section{Kata Kunci : Tindak Tutur Direktif, Novel, Tinjauan Pragmatik}

\begin{abstract}
This research object to finding the description and explanation about the descriptive expression analysis in the novel "Belenggu" by Armijn Pane (a pragmatic observation). The sort of this research is the library research with the descriptive quantitative which used the pragmatic theory planning. The data source in this research is the novel from Armijn Pane "Belenggu". The data result shows that the directive expression which found in novel "Belenggu" by Armijn Pane, deals with three kinds, such as : (1) imperatife sentence; (2) introgative sentence; (3) declarative sentence. That directive expression appearance is used in the expression of order command, request, suggestion, asking, invication, resistance, advice and prohibition. The directive expression in Belenggu novel by Armijn Pane is applied with the various expression modus and with the social relationship based on the socioculture norm that they have.
\end{abstract}

Key Words : Directive expression, novel, pragmatic observation.

\section{PENDAHULUAN}

Kalimat yang dituturkan oleh tokoh-tokoh yang digambarkan pengarang dalam sebuah novel diharapkan dapat dipahami dengan baik oleh pembaca serta menggunakan kalimat yang sopan dan tidak menimbulkan kesalahpahaman. Namun kenyataannya tuturan-tuturan tersebut sebagian dapat dipahami oleh pembaca secara langsung dan ada pula yang tidak serta munculnya bahasa-bahasa yang dianggap kurang santun. Oleh karenanya makna setiap tuturan harus ditafsirkan sesuai dengan konteks yang melatarinya. Tuturan yang sama apabila disampaikan dalam konteks yang berbeda dapat memberikan makna yang berbeda pula. Dengan kata lain, keberhasilan mitratutur menafsirkan sebuah tuturan didasarkan pada pemahaman konteks yang melatari terjadinya tuturan. Gejala-gejala seperti ini banyak dijumpai pada percakapan dalam sebuah novel. Oleh karena itu, pembaca perlu mengerti akan pragmatik dan bagaimana mengetahui apakah yang 
dihadapi sebuah fenomena pragmatis. Pragmatik bermanfaat dalam proses belajar bahasa sebab mengajarkan seseorang dapat bertutur kata tentang makna yang dimaksudkan, asumsi mereka, maksud atau tujuan mereka, dan jenis-jenis tindakan yang mereka perlihatkan ketika mereka sedang berbicara (Yule, 2006:5).

Penelitian ini akan mengakaji tentang makna yang terkandung dalam suatu tuturan, dalam hal ini tuturan yang dimaksudkan merupakan perkataan yang disampaikan oleh penutur yang disesuaikan dengan kondisi waktu, tempat, dan kepada siapa tuturan tersebut ditujukan. Dalam usaha untuk mengungkapkan diri mereka, orang-orang tidak hanya menghasilkan tuturan yang mengandung kata-kata dan strukturstruktur gramatikal saja, tetapi mereka juga memperlihatkan tindakan-tindakan melalui tuturan-tuturan itu. Salah satu bidang kajian pragmatik yang menjadi fokus peneliti yaitu tindak tutur, hal ini disebabkan karena adanya fenomena penggunaan bahasa dalam sebuah novel ketika berinteraksi yang sering kali kurang dipahami oleh pendengar atau pembaca. Oleh karena itu, agar terhindar dari kegagalan berkomunikasi, baik penutur dan mitratutur hendaknya memiliki kompetensi komunikasi yang mengacu pada pengetahuan dan keterampilan komunikatif yang samasama dimiliki.

Dalam setiap tuturannya seseorang tidak hanya sekadar bertutur saja tetapi juga harus mempetimbangkan faktorfaktor kesopanan seperti, kepada siapa tuturan itu ditujukan, dimana, dalam situasi apa, dan apa tujuannya. Hal tersebut berguna dalam membina hubungan yang wajar dan santun antarpelaku tutur. Salah satu bentuk tindak tutur ilokusi yang melibatkan sopan santun ialah tindak tutur direktif. Tindak tutur direktif merupakan jenis tindak ilokusi yang bertujuan menghasilkan suatu efek berupa tindakan yang dilakukan oleh petutur; ilokusi ini, misalnya, memesan, memerintah, memohon, menuntut, dan memberi nasihat (Suyono, 1990:6). Jenis ilokusi ini melibatkan sopan santun yang tujuannya ialah mengurangi ketidakharmonisan yang tersirat dalam sabuah tuturan, dengan demikian tindak tutur direktif ini dibutuhkan untuk memperlembut sifat tidak sopan yang secara intrinsik terkandung dalam tujuan sebuah tuturan (Leech, 1993:162-163).

Novel merupakan wacana tulis yang menyertakan tuturan percakapan yang konkret yang dilakukan oleh tokohtokoh. Pengarang mengungkapkan tuturan-tuturan setiap tokoh dalam bentuk dialog namun kadang tuturan-tuturan tersebut sulit untuk dimengerti dan dipahami oleh pembacanya. Oleh karena itu, penulis menganggap tindak tutur direktif dalam sebuah novel sangat penting untuk diteliti karena analisis ini sangat bermanfaat untuk menggambarkan jenis-jenis tindakan yang dapat kita lakukan dengan kata-kata dan pengidentifikasian beberapa bentuk tuturan konvensional yang kita gunakan untuk menampilkan tindakan khusus. Penulis dalam hal ini memilih novel Belenggu karya Armijn Pane dengan asumsi isi novel tersebut mengandung salah satu unsur tindak tutur direktif yakni tindak tutur tulisan yang dapat digunakan dalam penelitian. Novel tersebut juga mengandung tuturan yang sarat dengan nilai-nilai kesopanan sebab masih dipengaruhi oleh norma-norma sosial dan budaya pada masanya, berbeda dengan penggunaan bahasa novel-novel sekarang ini yang kadang menyalahi norma-norma sosial yang ada karena 
norma sosial dan budaya suatu masyarakat senantiasa berubah seiring dengan pesatnya perkembangan zaman dan ilmu pengatahuan.

Penelitian ini mengkaji lebih dalam mengenai makna dan fungsi yang terkandung dalam sebuah tuturan dalam bentuk naskah tertulis. Penelitian sebelumnya hanya meneliti wujud-wujud tindak tutur direktif tanpa mengaitkan dengan makna serta fungsi yang terkandung dalam tuturan tersebut dan kebanyakan dengan menggunakan objek alamiah sedangkan dalam penelitian ini lebih memilih novel sebagai objek kajiannya. Hal ini pula yang membedakan penelitian ini dengan penelitian-penelitian sebelumnya.

\section{METODE}

Penelitian ini adalah penelitian kebahasaan yang memfokuskan pada bidang pragmatik. Dalam penelitian ini penulis lebih menekankan pada analisis mengenai tindak tutur direktif dalam novel. Oleh karena itu, metode yang digunakan adalah metode deskriptif yang menggunakan pendekatan kualitatif. Data yang terkumpul berbentuk kata-kata atau gambar, sehingga tidak menekankan pada angka.

Data penelitian ini adalah pernyataan berupa kalimat atau paragraf yang mengandung tindak tutur direktif yang terdapat dalam novel Belenggu karya Armijn Pane. Pengumpulan data dalam penelitian ini dilakukan dengan menggunakan teknik baca, teknik identifikasi yang termasuk ke dalam ilokusi, klasifikasi berdasarkan identifikasi ilokusi, dan identifikasi berdasarkan klasifikasi. Sumber data penelitian ini adalah novel Belenggu karya Armijn Pane, cetakan keduapuluh satu, tahun 2008, penerbit Dian Rakyat, dengan jumlah halaman 150 lembar. Pengumpulan data dalam penelitian ini dilakukan dengan menggunakan teknik baca, teknik identifikasi yang termasuk ke dalam ilokusi, klasifikasi berdasarkan identifikasi ilokusi, dan identifikasi berdasarkan klasifikasi.

\section{HASIL}

Dalam novel Belenggu karya Armijn Pane memuat tentang gambaran tindak tutur direktif dalam kehidupan yang dikisahkan oleh pengarang melalui karyanya. Tindak tutur direktif yang diwujudkan dengan modus yang berbedabeda, yaitu deklaratif, imperatif, dan introgatif, serta dengan fungsi yang bervariasi, yaitu tindak tutur memesan, memerintah, memohon, menyarankan, meminta, mengajak, menentang, menasihati dan melarang. Setiap tindak tutur direktif dalam novel tersebut akan dikaji pada bagian berikut :

\section{a. Wujud Tindak Tutur Direktif dalam Novel Belenggu}

\section{1) Imperatif}

Tindak tutur direktif yang termasuk dalam kategori ini dapat dilihat pada contoh di bawah ini:

(Data 1) Tono : "baiklah, Har. Kalau kebetulan aku tiada di rumah, tunggulah di ruang tengah. Tanyalah bujang kapan aku kembali." (Blg:110)

Hartono : "Hm...(hanya diam sambil tertunduk)

(konteks : dituturkan di rumah Tono pada sore hari dengan situasi santai. Tono dan Hartono memiliki hubungan persahabatan)

Tuturan tersebut dituturkan Tono kepada Hartono yang memiliki hubungan persahabatan. Tindak tutur yang disampaikan di atas menggunakan tuturan imperatif dengan penanda kata tunggulah dan tanyalah pada tuturan tersebut. 


\section{2) Introgatif}

Tindak tutur direktif yang termasuk dalam kategori ini dapat dilihat pada contoh di bawah ini:

(Data 1) Tono : "No, dimana blocnote?" (Blg:15)

(konteks: keempat tuturan di atas berlangsung di ruang kerja Tono. Tuturan disampaikan Tono kepada pembantunya)

(Data 46) Yah : "Katakanlah apa yang ketahuan?" (Blg:44)

(konteks : tuturan antara Tono dan Yah berlangsung di rumah Yah pada sore hari)

(Data 56) Yah : "Coba lihat plaat ini suara siapa?" (Blg:75)

(Data 57) Yah : "Tono coba dengarkan suara siapa?" (Blg:75)

Data 1 dituturkan Tono kepada Karno ketika mencari blocnotenya. Tuturan tersebut disampaikan dengan tuturan introgatif dengan penanda tanya pada akhir kalimat. Sedangkan data 46 dituturkan Yah menggunakan tuturan introgatif dengan penanda Tanya pada akhir kalimat. Data 56, data 57 dituturkan Yah menggunakan tuturan introgatif dengan penanda tanya pada akhir kalimat.

\section{3) Deklaratif}

Tindak tutur direktif yang termasuk dalam kategori ini dapat dilihat pada contoh di bawah ini:

Nyonya?"

Tono : "Bagaimana rasa

(Data 24) Yah : “dingin panas, tuan dokter, tapi tidak sepanjang hari, pagi-pagi saja habis bangun.” (Blg:21)

Tono : “...(maka dimulainya memeriksa dengan memakai stethoscoop)

(konteks : tuturan berlangsung di kamar Yah. Tuturan disampaikan Tono (dokter) kepada Yah (pasien) (Data 27) Yah : "kata orang, tuan dokter sering juga mengungjungi pasien lama yang sudah sembuh.” (Blg:28)

(konteks : tuturan berlangsung di ruang tamu rumah Yah pada sore hari)
Data 24 dan data 27 adalah tuturan Yah menggunakan tuturan deklaratif. Pada data 24 terlihat bahwa Yah menginformasikan mengenai kesehatannya kepada Tono sedangkan pada data 27 Yah memberitahukan kepada Tono mengenai informasi yang didengarnya.

\section{b. Fungsi Tindak Tutur Direktif dalam Novel Belenggu}

\section{Memesan}

Tindak tutur memesan merupakan realisasi fungsi tidak tutur direktif dalam dalam novel Belenggu. Dari analisis data ditemukan tindak tutur memesan. Tindak tutur memesan termasuk realisasi fungsi meyakinkan atau mempengaruhi mitra tutur supaya melakukan sesuatu tindakan yang dikehendaki oleh penutur. Tindak tutur tersebut dapat dilihat pada contoh di bawah ini:

(Data 1) Tono : "baiklah, Har. Kalau kebetulan aku tiada di rumah, tunggulah di ruang tengah. Tanyalah bujang kapan aku kembali." (Blg:110)

Hartono : "Hm...(hanya diam sambil tertunduk)

(konteks : dituturkan di rumah Tono pada sore hari dengan situasi santai. Tono dan Hartono memiliki hubungan persahabatan)

Data percakapan di atas dituturkan Tono kepada Hartono dengan maksud memesan atau berpesan. Walaupun tindak tutur memesan yang dinyatakan Tono disampaikan menggunakan tuturan imperatif, tetapi fungsi tindak tutur memesan pada data percakapan di atas dilakukan Tono ketika hendak berpesan kepada Hartono agar dapat menunggunya nanti kalau dia datang lagi ke rumah Tono. 


\section{Memerintah}

Tindak tutur direktif dalam bentuk memerintah merupakan realisasi fungsi tindak tutur dalam novel Belenggu. Dari analisis data ditemukan tindak tutur direktif dalam bentuk memerintah. Tindak tutur memerintah termasuk realisasi fungsi bersosialisasi, yakni untuk keperluan beradabtasi, menjalin keakraban, dan menjalin hubungan dan keperluan kemasyarakatan. Kategori ini dapat dilihat pada contoh di bawah ini:

(Data 1) Tono : "No, dimana blocnote?" (Blg:15)

(Data 3) Tono : "No, dimana kau simpan?" (Blg:18)

Data percakapan 1 dituturkan Tono kepada Karno ketika mencari blocnotenya. Tuturan merupakan tindakan memerintah yang dilakukan oleh Tono terhadap Karno. Tindak tutur memerintah yang disampaikan seperti hanya bertanya kepada Karno, tetapi fungsinya untuk memerintah agar Karno mencari blocnote Tono. Tindak tutur memerintah yang dilakukan secara tidak langsung berarti Tono telah menggunakan tindak tutur direktif. Data percakapan 3 juga dituturkan Tono yang merupakan tindak memerintah yang disampaikan melalui pertanyaan, tetapi fungsinya untuk memerintahkan Karno mencari benda tersebut.

\section{Memohon}

Tindak tutur direktif dalam bentuk memohon merupakan realisasi fungsi tindak tutur direktif dalam novel Belenggu. Dari analisis data ditemukan tindak tutur direktif dalam tidak tutur memohon. Tindak tutur direktif dalam bentuk memohon termasuk realisasi fungsi tukar-menukar informasi intelektual, yakni untuk menyatakan permintaan atau pemberian izin terhadap sesuatu, yang termasuk dalam kategori ini dapat dilihat pada contoh di bawah ini:

(Data 25) Yah : "Maafkan saya, termenung. Patutlah tuan dokter menyindir." (Blg:22)

(konteks : tuturan berlangsung di ruang tamu rumah Yah pada sore hari)

(Data 40) Yah : “janganlah pergi, jangan aku tinggalkan; katamu biarlah lama-lama bermimpi. Engkau yang menahan harapan dalam hatiku. Ketika engkau tiada menerima ajakanku malam itu, aku sudah tidak hendak merangkap engkau lagi, tetapi engkau katakan : besok akan datang lagi. Timbul pula harapanku. Jangan kau tinggalkan, sudah lama aku mimpikan....., kita akan bersua kembali." (Blg :38)

(konteks : tuturan antara Tono dan Yah berlangsung di rumah Yah pada sore hari)

(Data 51) Yah : “Ampun, ampun Tono, biarlah kau pandang aku perempuan jahat." (Blg:46)

(konteks : tuturan berlangsung pada malam hari di ruang tengah rumah $\mathrm{Yah}$ )

Data percakapan 25 di atas merupakan tuturan Yah saat menyadari perkataan Tono yang menyindirnya. Tuturan disampaikan dengan rasa bersalah Yah karena termenung karena itu ia menyampaikan permohonan maaf kepada Tono, demikian pula pada data percakapan 40 di atas dituturkan Yah yang fungsinya memohon agar Tono meyakini dan percaya bahwa Yah benarbenar mencintainya, walaupun dalam tuturan tersebut menggunakan kalimat perintah secara halus. Data percakapan 51 merupakan tuturan yang disampaikan Yah yang fungsinya meminta maaf kepada Tono. Namun demikian, tuturan yang dilakukan seolah-olah hanya memberitahukan saja. 


\section{Menyarankan}

Tindak tutur direktif dalam bentuk menyarankan merupakan realisasi fungsi tindak tutur direktif dalam novel Belenggu. Dari analisis data ditemukan tindak tutur direktif dalam bentuk menyarankan. Tindak tutur direktif dalam bentuk menyarankan termasuk realisasi fungsi tukar-menukar sikap moral, yaitu untuk mengekspresikan berbagai sikap dan pandangan moral, misalnya penilaian baik atau buruk, benar atau salah terhadap sikap tertentu. Berikut yang termasuk dalam kategori ini dapat dilihat pada contoh di bawah ini:

(Data 7) Tono : "tidak perlu nyonya buka." (Blg:21)

(konteks : tuturan berlangsung di kamar Yah. Tuturan disampaikan Tono (dokter) kepada Yah (pasien)

(Data 12) Tono : "tidak mengapa, tiada lagi,...tetapi bolehkah saya menelpon dulu, bertanya ke rumah?...kalau ada, tiada usah lagi pulang, dapat terus," (Blg:28)

(konteks : tuturan berlangsung di ruang tamu rumah Yah pada sore hari)

Data 35) Yah : "Dokter, tidakkah panas hari ini? Bolehkah saya tanggalkan baju tuan dokter?" (Blg:33)

(konteks : tuturan berlangsung di rumah Yah pada malam hari)

Data percakapan 7 di atas merupakan tuturan Tono ketika memeriksa kesehatan Yah. Tuturan merupakan penilaian Tono terhadap sikap Yah yang berlebihan. Tuturan ini dimaksudkan untuk memberi saran kepada Yah agar tidak perlu membuka bajunya, tuturan tersebut sifatnya tidak memaksa. Oleh karena itu Tono menuturkannya seperti memerintahkan. Sedangkan percakapan data 12 disampaikan Tono ketika selesai memeriksa kesehatan Yah. Tuturan pada data 12 mengandung maksud menyarankan agar Tono menelpon dulu ke rumah untuk memastikan tidak ada lagi pasien yang akan diperiksanya supaya Tono bisa lebih lama di rumah Yah. Data 12 dituturkan seperti hanya menginformasikan saja dan sifatnya tidak memaksa. Data percakapan 35 dituturkan Yah ketika Tono berkunjung ke rumahnya. Tuturan tersebut mengandung maksud agar Tono membuka baju hangat yang dikenakannya dan juga agar Tono bisa lebih lama berada di rumah Yah. Walaupun demikian, data 35 di atas dituturkan seperti hanya bertanya saja yang sifatnya tidak memaksa untuk dilakukan.

\section{Meminta}

Tindak tutur direktif dalam bentuk meminta merupakan realisasi fungsi tindak tutur dalam novel Belenggu. Dari analisis data ditemukan tindak tutur direktif dalam bentuk meminta. Tindak tutur memerintah termasuk realisasi fungsi tukar-menukar informasi intelektual, yakni untuk menyatakan permintaan dan pemberian izin. Kategori ini dapat dilihat pada contoh di bawah ini:

tuan dokter?" (Blg:28)

(Data 29) Yah : "Nomor berapa

(konteks : tuturan berlangsung antara Yah dan Tono, di rumah Yah)

(Data 100) Tono : “apa perlunya cemburu...jadi aku tolak saja .." (Blg:96) permintaan?...

(konteks : tuturan berlangsung pada tengah malam di rumah Yah)

Pada data percakapan 29 di atas tampak tuturan Yah mengandung maksud meminta nomor telepon rumah Tono. 
Sedangkan data 100 dituturkan Tono mengandung maksud meminta izin Yah untuk menerima tawaran temantemannya menjadi juri lomba bayi sehat. Walaupun kedua data di atas mengandung maksud meminta tetapi penuturannya seperti bertanya.

\section{Mengajak}

Tindak tutur direktif yang termasuk dalam kategori ini dapat dilihat pada contoh di bawah ini:

(Data 13) Yah : "Alangkah sedapnya turun ke Priok.” (Blg:29)

$$
\begin{aligned}
& \text { Tono : "Ya, benar," } \\
& \text { Yah : "sendirian," } \\
& \text { Tono : "Bukan, dengan }
\end{aligned}
$$

nyonya,...kalau suka.” (Blg:29)

(Data 14) Tono : "kata dokter juga, nyonya mesti banyak melalaikan pikiran,...dan si sakit mesti menurut kata dokter." (Blg:29)

Yah : “...(tertawa, lalu masuk kamar mengambil selendang)

(konteks : tuturan berlangsung di rumah Yah pada sore hari)

Data 13 dituturkan Yah ketika melihat Tono merasa tidak ingin pulang ke rumahnya. Tuturan tersebut mengandung maksud mengajak Tono jalan-jalan ke pantai Priok. Data 14 dituturkan Tono kepada Yah ketika mengajak Yah keluar jalan-jalan. Walaupun kedua tuturan di atas bermaksud untuk mengajak tetapi pengungkapannya seperti menginformasikan saja.

\section{Menentang}

Tindak tutur direktif dalam bentuk menentang merupakan realisasi fungsi tindak tutur direktif dalam novel Belenggu. Dari analisis data ditemukan tindak tutur direktif dalam tidak tutur menentang. Tindak tutur direktif dalam bentuk menentang termasuk realisasi fungsi tukar-menukar informasi intelektual, yakni untuk menyatakan setuju atau tidak setuju, yang termasuk dalam kategori ini dapat dilihat pada contoh di bawah ini:

(Data 17) Tono : "Mimpi? Ini bukan mimpi. Kemaren barangkali belum dapat dimimpikan akan begini." (Blg:33)

(konteks : tuturan berlangsung di rumah Yah pada malam hari. Tuturan antara Tono dan Yah)

(Data 20) Tono : "bukan kau bilang, tiada usah dijemput?” (Blg:35)

Tini : "siapa bilang? Bukan kau yang mengatakan hendak menjemput aku?"

Tono : "bukan kau diam saja?"

(konteks : tuturan antara Tono dan Tini berlangsung di ruang tengah rumah Tono pada malam hari dengan suasana yang agak tegang)

Pada data 17 merupakan tuturan Tono kepada Yah yang seolah-olah seperti bertanya saja tetapi maksudnya yaitu untuk menentang perkataan lawan tuturnya. Data percakapan 17 dituturkan Tono ketika menganggap apa yang dikatakan Yah itu tidak benar. Jadi, maksud dari data 17 yaitu Tono menentang aggapan dan perkataan Yah yang menganggap bahwa kedekatan antara mereka berdua telah lama diimpikan Yah, namun Tono menganggap bahwa pertemuan mereka hanya kebetulan. Data 20 dituturkan Tono yang seolah-olah bertanya dengan maksud menentang perkataan Tini yang menganggap bahwa Tono akan menjemputnya.

\section{Menasihati}

Tindak tutur direktif dalam bentuk menasihati merupakan realisasi fungsi tindak tutur direktif dalam novel Belenggu. Dari analisis data ditemukan tindak tutur direktif dalam tidak tutur menasihati. Tindak tutur direktif dalam bentuk menasihati termasuk realisasi fungsi tukar-menukar emosi untuk 
mengekspresikan berbagai sikap dan pandangan moral, misalnya penilaian baik atau buruk, benar dan salah terhadap sikap tertentu, yang termasuk dalam kategori ini dapat dilihat pada contoh di bawah ini:

(Data 9) Tono : "Tidak selamanya hari hujan, besok lusa akan panas juga.” (Blg:22)

(konteks : tuturan berlangsung di rumah Yah. Tuturan antara Tono dan Yah)

(Data 101) Paman Tini : “jangan dengan angkara murka, hendaklah dengan sabar juga. Sabar, bukan tanda kalah, melainkan tanda seimbang, tanda sama tengah yang sejati, pangkal mula kehidupan yang benar. Ialah salah satu keadaan pikiran dan selidik yang sebaik-baiknya, hampir tiada bergerak, dalam menjalankan ikhtiar. Itulah perbuatan semangat suci yang seutamautamanya, waktu yang sebaik-baiknya untuk berdaya upaya.” (Blg:126)

(konteks : tuturan berlangsung tengah malam antara Tono dan paman Tini di ruang tengah rumah Tono dengan suasana yang sedikit tegang)

Data percakapan 9 merupakan tuturan Tono kepada Yah dengan maksud menasihati Yah agar tidak bersedih tetapi dituturkan Tono dengan modus deklaratif tetapi berfungsi untuk menasihati yang cenderung dituturkan oleh penutur yang memiliki status sosial lebih tinggi dan usia yang lebih tua. Sedangkan data percakapan 101 juga dituturkan oleh Paman Tini tetapi dengan menggunakan kalimat yang seolah-olah hanya memberitahukan saja tanpa memaksakan tetapi maksudnya yaitu menasihati Tono agar bisa lebih sabar dalam menghadapi setiap masalah dalam keluarga.

\section{Melarang}

Tindak tutur direktif dalam bentuk melarang merupakan realisasi fungsi tindak tutur direktif dalam novel Belenggu. Dari analisis data ditemukan tindak tutur direktif dalam tidak tutur melarang. Tindak tutur direktif dalam bentuk melarang termasuk realisasi fungsi meyakinkan atau mempengaruhi untuk meyakinkan mitratutur supaya melakukan sesuatu tindakan yang dikehendaki oleh penutur, yang termasuk dalam kategori ini dapat dilihat pada contoh di bawah ini:

(Data 30) Yah : “jangan terlalu cepat dokter, saya kuatir. Disini banyak kecelakaan.” (Blg:29) (konteks : tuturan berlangsung antara Tono dan Yah, di jalan menuju Priok)

(Data 48) Yah : “Ah, suamiku, apakah perlunya berpikir? Berpikir itu menyusahkan diri. Kau sudah banyak berpikir, apa perlunya lagi dipikirkan tentang pikiran orang lain? Kita sudah banyak berkata-kata, apa perlunya diketahu kata orang lain?" (Blg:45)

Data percakapan 30 merupakan tuturan Yah yang mengandung maksud melarang Tono agar tidak melajukan mobilnya terlalu cepat walaupun dengan modus tuturan deklaratif tetapi berfungsi untuk melarang. Data percakapan 48 merupakan tuturan Yah yang mengandung maksud melarang Tono supaya tidak peduli dengan apa yang dikatakan orang lain mengenai hubungannya. Tetapi dituturkan dengan kalimat yang seolah-olah hanya bertanya saja.

\section{PEMBAHASAN}

\section{Wujud Tindak Tutur Direktif dalam Novel Belenggu Karya Armijn Pane}

Berdasarkan hasil analisis data yang telah dikemukakan, temuan penelitian menunjukkan bahwa bentuk atau wujud tindak tutur direktif dalam 
percakapan pada novel Belenggu karya Armijn Pane tersebut dinyatakan dengan tuturan yang bermodus imperatif, introgatif, dan deklaratif. Bentuk atau wujud tuturan tindak tutur direktif yang demikian itu menunjukkan maksud yang berbeda-beda. Hal itu dipengaruhi oleh konteks penggunaannya termasuk norma sosial penutur dan mitra tuturnya.

Bentuk atau wujud tindak tutur direktif yang bermodus imperatif digunakan untuk menyatakan perintah, tindak memesan, permohonan, menyatakan saran, nasihat, dan larangan. Wujud tindak tutur direktif yang bermodus imperatif dalam menyatakan perintah dan larangan berorientasi pada solidaritas tinggi dan berasosiasi dengan posisi kehormatan atau kedudukan yang lebih tinggi yang dimiliki penutur dari pada mitra tutur; yang menyatakan tindak memesan, menyatakan saran, dan nasihat berorientasi kepada solidaritas sosial dan berasosiasi dengan ketegasan yang terkesan seperti dinyatakan oleh penutur kepada mitra tutur dalam hubungan yang sejajar; yang menyatakan tindak permohonan menunjukkan adanya kesantunan yang berorientasi kepada solidaritas sosial sebagai wujud adanya hubungan kasih sayang dan tidak terlalu menonjolkan penghormatan terhadap status penutur atau mitra tutur yang lebih tinggi atau lebih tua.

Bentuk atau wujud tindak tutur direktif yang bermodus introgatif digunakan untuk menyatakan perintah, permohonan, menyatakan saran, permintaan, menentang, dan larangan. Bentuk atau wujud tindak tutur direktif dengan modus tuturan introgatif dalam menyatakan perintah, menentang, dan larangan berorientasi kepada solidaritas sosial dan berasosiasi dengan ketegasan; permintaan, permohonan, dan menyatakan saran berorientasi kepada keseganan dan menunjukkan adanya kesantunan sebagai wujud pertalian kasih sayang, tanpa terlalu menonjolkan penghormatan terhadap status kedudukan atau usia.

Bentuk atau wujud tindak tutur direktif dengan modus tuturan deklaratif digunakan untuk menyatakan permohonan, saran, mengajak, nasihat, dan larangan. Bentuk atau wujud tindak tutur direktif dengan modus tuturan deklaratif dalam menyatakan permohonan dan mengajak berorientasi kepada solidaritas sosial yang menunjukkan adanya kesantunan yang hanya sekadar untuk menjalin hubungan keakraban; saran dan nasihat menunjukkan adanya kesantunan yang berorientasi kepada solidaritas sosial yang berasosiasi dengan pemberian alternatif yang sifatnya tidak tegas; menentang dan melarang berorientasi terhadap kesantunan yang sifatnya tidak tegas.

Bentuk dan wujud tindak tutur direktif seperti yang telah dijelaskan di atas secara teoretis, sejalan dengan pandangan yang menyatakan bahwa secara formal bentuk atau wujud tindak tutur berdasarkan modusnya dibedakan menjadi kalimat berita (deklaratif), kalimat tanya (introgatif), dan kalimat perintah (imperatif) baik itu secara langsung maupun tidak langsung (Wijana, 1996). Faktor usia merupakan salah satu hal yang mempengaruhi penggunaan bahasa seseorang (Sumarsono, 2004:135). Penggunaan kata berkaitan dengan kewenangan dan solidaritas (Tannen dalam Syafruddin, 2010).

\section{Fungsi Tindak Tutur Direktif dalam Novel Belenggu Karya Armijn Pane}

Berdasarkan hasil analisis data yang telah dikemukakan pada bagian 
sebelumnya, bagian ini dibahas tentang fungsi tindak tutur direktif yang ditemukan dalam novel Belenggu karya Armijn Pane meliputi : (1) memesan; (2) memerintah; (3) memohon; menyarankan; (5) meminta; (6) mengajak; (7) menentang; (8) menasihati; (9) melarang. Fungsi tindak tutur direktif dalam percakapan yang bervariasi dan masing-masing diwujudkan dengan tuturan yang berbeda-beda. Hal tersebut dipengaruhi oleh konteks penggunaannya (1) norma sosial yang berupa peran peserta komunikasi, status hubungan, situasi tempat komunikasi, usia, pendidikan, dan jenis kelamin; (2) norma budaya berupa adat istiadat, sistem nilai budaya, dan religi yang berlaku. Berikut uraian uraian yang menyatakan fungsi tindak tutur direktif dalam novel Belenggu karya Armijn Pane.

Pertama, fungsi tindak direktif memesan tersebut diwujudkan dengan tuturan yang bermodus imperatif. Fungsi tindak tutur direktif memesan tersebut terkesan santai, hal tersebut disebabkan oleh faktor usia dan status hubungan antara penutur dan mitra tutur yang merupakan teman dekat. Tindakan memesan atau berpesan yang dinyatakan Tono kepada sahabatnya Hartono dengan modus imperatif berorientasi pada solidaritas sosial yang tinggi seperti hubungan yang sejajar.

Kedua, tindak tutur direktif yang menyatakan maksud memerintah dalam novel diwujudkan dengan modus imperatif, introgatif, dan deklaratif. Tindak tutur direktif yang berfungsi untuk memerintah, (1) dinyatakan oleh penutur yang mempunyai kedudukan dan status sosial yang lebih tinggi disbanding mitra tuturnya yang mempunyai kedudukan yang lebih rendah dan tingkat solidaritas yang tinggi; (2) dinyatakan oleh penutur yang mempunyai kedudukan dan status sosial yang sejajar dengan mitra tuturnya. Tindak tutur yang berfungsi untuk memerintah secara langsung cenderung lebih tegas, terutama perintah langsung yang dinyatakan oleh penutur yang mempunyai kedudukan dan status sosial yang lebih tinggi seperti tuturan yang disampaikan oleh atasan terhadap bawahan.

Ketiga, tindak tutur direktif yang berfungsi untuk memohon dituturkan dengan modus imperatif, introgatif, dan deklaratif. Memohon berarti tuturan itu terimplikasi suatu permintaan penutur yang amat sangat kepada mitra tuturnya. Tindak tutur direktif dalam bentuk memohon termasuk realisasi fungsi tukarmenukar informasi intelektual, yakni untuk menyatakan permintaan atau pemberian izin terhadap sesuatu. Tindak tutur direktif dengan wujud memohon dalam novel ini cenderung dinyatakan secara langsung.

Keempat, tindak tutur direktif dapat berfungsi untuk menyarankan secara langsung dan tidak langsung. Menyarankan berarti pernyataan penutur tersebut memberikan masukan pada mitra tuturnya untuk melakukan sesuatu. Tindak tutur direktif yang berfungsi untuk menyarankan tersebut diwujudkan dengan tuturan bermodus imperatif, introgatif, dan deklaratif. Percakapan dalam novel menyatakan tindak tutur direktif yang berfungsi untuk menyarankan pada umumnya terkesan tidak tegas dan hanya sekadar untuk menjalin hubungan solidaritas seperti dalam hubungan sajajar, seperti tuturan yang dinyatakan Yah terhadap Tini yang berfungsi memberi saran agar Tono tidak meninggalkan Tini demi wanita lain. Pernyataan Yah dimaksudkan sebagai ajaran agar Tini dapat berlaku sebagaimana mestinya dan berperilaku yang baik terhadap suaminya. Saran yang 
disampaikan Tono terhadap Yah terkesan tidak tegas dan berorientasi kepada keakraban.

Kelima, tindak tutur direktif yang berfungsi untuk meminta secara langsung yang meliputi meminta informasi dan meminta konfirmasi. Permintaan tersebut diwujudkan dengan tuturan dengan modus introgatif. Tindak tutur direktif dalam novel Belanggu yang berfungsi untuk meminta secara langsung pada umumnya terkesan tidak tegas, (1) tuturan yang menyatakan meminta informasi dari Yah terhadap Tono disampaikan disampaikan secara langsung berorientasi kepada hubungan solidaritas sosial rendah dan berasosiasi dengan keseganan; (2) tuturan yang menyatakan meminta konfirmasi dinyatakan oleh Tono terhadap Yah yang disampaikan dengan cara yang tidak tegas. Hal tersebut menunjukkan adanya tindakan tidak sewenang-wenang dan dimaksudkan sebagai bentuk empati untuk memantapkan hubungan yang harmonis.

Keenam, tindak tutur direktif yang berfungsi untuk mengajak secara tidak langsung digunakan oleh penutur ketika menginginkan agar mitra tuturnya ikut melakukan sesuatu seperti apa yang dilakukan penutur. Tindak tutur direktif yang berfungsi untuk mengajak tersebut diwujudkan dengan modus deklaratif. Tuturan mengajak yang dilakukan umumnya terkesan tidak tegas. Tuturan yang dinyatakan Tono terhadap Yah berorientasi kepada solidaritas sosial tinggi seperti terhadap teman akrab atau hubungan yang sejajar.

Ketujuh, tindak tutur direktif yang berfungsi untuk menentang digunakan oleh penutur ketika menyatakan ketidaksetujuannya terhadap sesuatu agar mitra tuturnya melakukan sesuatu seperti apa yang diinginkannya. Tindak tutur direktif yang berfungsi untuk menentang diwujudkan dengan modus tuturan introgatif dan deklaratif yang pada umumnya tidak tegas dan menunjukkan solidaritas sosial karena adanya kesejajaran hubungan antara penutur dan mitra tutur. Tuturan yang disampaikan Tono terhadap Yah dan Tini dengan modus tuturan introgatif yang berorientasi kepada solidaritas sosial rendah seperti penutur dan mitra tutur yang mempunyai hubungan yang sejajar. Hal itu dilandasi kasih sayang, saling menghormati, dan saling menghargai.

Kedelapan, tindak tutur direktif yang berfungsi untuk menasihati secara langsung dan tidak langsung. Menasihati berarti pernyataan penutur tersebut berisi nasihat-nasihat yang baik kepada mitra tuturnya. Nasihat tersebut diwujudkan dengan modus tuturan imperatif dan deklaratif. Umumnya tindak tutur direktif yang berfungsi untuk menasihati disampaikan oleh penutur dari kedudukan dan status yang tinggi ke mitra tutur dengan status yang rendah atau oleh penutur ke mitra tutur dengan status yang sejajar. Nasihat yang dinyatakan Nyonya Rusdio terhadap Tini dan Paman Tini terhadap Tono cukup tegas dan berorientasi kepada solidaritas sosial tinggi. Ketegasan nasihat Nyonya Rusdio terhadap Tini dan Paman Tini terhadap Tono tergolong santun. Hal tersebut guna mendidik Tini atau Tono yang dilandasi kasih sayang, saling peduli, saling mengingatkan, dan saling menghargai. Sedangkan nasihat yang dinyatakan Tono terhadap Yah atau sebaliknya, Yah terhadap Tini, dan Hartono terhadap Tini terkesan lebih halus atau lebih santun daripada nasihat yang dinyatakan oleh penutur yang memiliki status lebih tinggi daripada mitra tuturnya, seperti tuturan yang dinyatakan Nyonya Rusdio terhadap Tini dan tuturan yang dinyatakan oleh 
Paman Tini terhadap Tono. Hal tersebut berkaitan dengan hal-hal yang tidak serius.

Kesembilan, tindak tutur direktif yang berfungsi untuk melarang meliputi melarang secara langsung dan tidak langsung yang dinyatakan dengan modus imperatif, introgatif, dan deskriptif. Tindak tutur melarang digunakan penutur ketika menginginkan mitra tuturnya tidak melakukan sesuatu yang tidak diinginkan penutur. Tindak tutur melarang baik langsung maupun tidak langsung ada yang terkesan tegas dan ada yang terkesan tidak tegas. Tuturan yang terkesan tegas maupun tidak tegas juga tergantung konteksnya (siapa peserta komunikasi, status hubungan, situasi tempat komunikasi, usia, pendidikan, dan jenis kelamin. Tuturan yang dinyatakan Yah terhadap Tini terkesan cukup tegas karena berada dalam situasi yang tegang, dimana Yah marah karena dimaki-maki oleh Tini. Hal ini dilandasi upaya memberitahukan agar Tini tidak bersikap demikian lagi. Tuturan yang dinyatakan Tono terhadap Yah atau sebaliknya terkesan tidak tegas. Hal ini disebabkan karena Tono menghargai Yah dan begitupun sebaliknya dan hanya untuk menjalin hubungan solidaritas sosial sehingga terkesan dalam hubungan yang sejajar.

Temuan penelitian sebagaimana telah disampaikan tersebut menunjukkan bahwa fungsi tindak tutur direktif dalam percakapan pada novel Belenggu sangat bervariasi. Fungsi tindak tutur direktif yang bervariasi tersebut diwujudkan dengan modus tuturan imperatif, introgatif, dan deklaratif dan dengan intonasi yang berbeda-beda. Hal itu disebabkan oleh adanya perbedaan status dan peran partisipan, kaidah hubungan interaksi sehubungan dengan struktur sosial, dan pemilihan ujaran berdasarkan norma sosial budaya yang berlaku, sejalan dengan perubahan situasi pada tempat interaksi terjadi.

Berdasarkan uraian yang telah disampaikan menunjukkan bahwa dalam menyatakan berbagai fungsi tindak tutur direktif yang dinyatakan oleh para tokoh dalam novel Belenggu selalu mempertimbangkan faktor pilihan kata atau pilihan bahasa yang akan digunakan agar sesuai dengan maksud dan tujuan penutur sehingga mitra tutur dapat memahami maksud tuturan tersebut. Hal tersebut sejalan dengan pandangan Leech (dalam Rahardi, 2005:66) yang menyatakan bahwa dalam mengekpresikan tindak atau fungsi tindak tutur diperlukan penggunaan pilihan kata atau pilihan bahasa sesuai dengan sifat fungsi tindak tutur itu sendiri.

\section{SIMPULAN}

Berdasarkan temuan penelitian, wujud tindak tutur direktif ditemukan dalam percakapan pada novel Belenggu. Wujud tindak tutur direktif dalam novel Belenggu terdapat dalam beberapa percakapan yang digunakan dengan modus yang bervariasi, berupa kalimat deklaratif, imperatif, dan interogatif. Wujud tindak tutur direktif itu menunjukkan adanya kesantunan yang berbeda-beda sesuai dengan konteks penggunaannya termasuk norma sosial penuturnya dan fungsi yang dinyatakannya yaitu, memesan, memerintah, memohon, menyarankan, meminta, mengajak, menentang, menasihati, dan melarang. Jadi dapat dikatakan bahwa penggunaan tindak tutur direktif dalam interaksi antartokoh dalam novel Belenggu karya Armijn Pane yang diungkapkan berorientasi pada penghormatan terhadap status yang lebih tinggi dan dengan usia yang lebih tua, 
bawahan terhadap atasan cenderung berorientasi pada kesantunan negatif. Hal itu sangat dipengaruhi oleh hubungan sosial antara penutur dan mitra tutur. Dalam hal ini pengarang sangat memperhatikan pemilihan ujaran tiap tokoh yang digambarkan dalam novel. Pemilihan ujaran ini biasanya berdasarkan norma sosial yang berlaku pada masanya.

\section{SARAN}

Kepada peneliti selanjutnya disarankan untuk mengadakan penelitian terhadap wujud dan fungsi tindak tutur pada ragam bahasa yang berbeda dengan penelitian ini dan konteks yang lain pula. Saran ini dikemukakan berkaitan dengan wujud dan fungsi yang disesuaikan dengan situasi sosial tertentu yang dalam kajian pragmatik termasuk penelitian sosiopragmatik. Kepada penikmat sastra khususnya novel maupun masyarakat pada umumnya disarankan memanfaatkan hasil penelitian ini untuk memperkaya wawasan berbahasa, memahami tindak tutur dan sikap seseorang dalam bertutur.

\section{DAFTAR PUSTAKA}

Leech, Geoffrey. 1993. Prinsip-prinsip Pragmatik. Diterjemahkan oleh Indonesian University. Jakarta : Universitas Indonesia.

Pane, Armijn. 2008. Belenggu. Jakarta : Dian Rakyat.

Rahardi, Kunjana. 2005. Pragmatik (Kesantunan Imperatif Bahasa Indonesia). Yogyakarta : Erlangga.

Sumarsono dan Paina Partana. 2004. Sosiolinguistik. Yogyakarta : Pustaka Pelajar.

Suyono. 1990. Pragmatik Dasar-dasar dan Pengajarannya. Malang : Yayasan Asih Asah Asuh Malang.

Syafruddin. 2010. Kesantunan Honorifik dalam Tindak Direktif Berbahasa Indonesia Keluarga Terpelajar
Masyarakat Tutur Makasssar. Disertasi. Malang : Universitas Negeri Malang.

Wijana, Dewaa Putu. 1996. Dasar-dasar Pragmatik. Yogyakarta : ANDI Yogyakarta.

Yule, George. 2006. Pragmatik. Diterjemahkan oleh Indah Fajar Wahyuni. Yogyakarta : Pustaka Pelajar. 